\title{
Effects of Different Iron Concentrations on Physiology of Prunus davidiana Seedlings
}

\author{
Liu Yang ${ }^{1}$, Bixia Zheng ${ }^{1}$, Xiao Zhang ${ }^{2}$, Tonghao Cui ${ }^{1}$, Xianmin Xia $^{1}$ and Ming'an Liao ${ }^{1 *}$ \\ ${ }^{1}$ College of Horticulture, Sichuan Agricultural University, Chengdu, Sichuan, 611130, China \\ ${ }^{2}$ Qionglai Agricultural and Rural Bureau, Chengdu, Sichuan, 611530, China
}

\begin{abstract}
In order to study the changes of the photosynthetic pigment content, antioxidant enzyme activity and osmotic adjuster content, the Prunus davidiana seedlings were cultured into Hoagland nutrient solution which added various concentrations of iron solution. Then the results showed that photosynthetic pigment content and antioxidant enzyme activity were all higher in iron-treated $P$. davidiana seedlings, compared with that in control seedlings. When increased iron concentration up to $10 \mathrm{mg} / \mathrm{L}$, the chlorophyll a, chlorophyll $\mathrm{b}$ and the total chlorophyll content gradually rose, but decreased at iron concentrations of 20, 30, 40 and $60 \mathrm{mg} / \mathrm{L}$. Irrigating iron concentration of $60 \mathrm{mg} / \mathrm{L}$ was the best way to increase the activity of superoxide dismutase (SOD), peroxidase (POD) and catalase (CAT), and malondialdehyde (MDA) content. But for chlorophyll $\mathrm{a} / \mathrm{b}$ ratio, it was the highest in no-iron seedlings. Moreover, the soluble protein content was the highest at iron concentration of $30 \mathrm{mg} / \mathrm{L}$, but the lowest at $10 \mathrm{mg} / \mathrm{L}$. Thus, the study concluded that irrigating iron solution could improve the growth and resistance to adverse circumstances of $P$. davidiana seedlings.
\end{abstract}

\section{Introduction}

Iron is an essential nutrient for plants and also affects individual's life span and the whole public health [1-2]. Iron deficiency causes a series of physiological changes. The leaves of plants develop yellow and the growth gets worse or interveinal chlorosis without iron, because this nutrient is indispensable in the electron transport chains of respiration and photosynthesis [3-4]. A previous study has shown that various concentrations iron solution effects of the photosynthesis and antioxidant system in pea seedlings [5]. Application of nano-iron oxide in the prevention and controls of iron deficiency yellowing disease in plants and that means promoting the antioxidant enzyme (POD, CAT and SOD) activity and photosynthetic pigment contents (chlorophyll a, chlorophyll b, carotenoid and total chlorophyll) [6].

Prunus davidiana, always as a good rootstock for stone fruit trees such as plums, cherries, apricots and other kinds of peaches, belongs to the genus peach of Rosaceae and has good drought resistance, salt and alkali resistance, good grafting affinity and so on [7-8]. Studies about the effects of iron on $P$. davidiana seedlings are not a lot and it's valuable to conduct a research for application of iron in fruit trees.

\section{Materials and methods}

\section{$2.1 \quad$ Materials}

This study selected $P$. davidiana seeds as materials to cultivate with perlite to explore the antioxidant enzyme activity and photosynthetic pigment contents in $P$. davidiana seedlings by irrigating iron solution. The nutrient solution for experiment was Hoagland which was bought online.

\subsection{Experimental design}

In February 2019, the material, $P$. davidiana seeds, was planted into perlite in climate chamber to culture. When the seedlings all reached a height of $10 \mathrm{~cm}$, nine uniformly growing $P$. davidiana seedlings were transplanted into a tray for water planting and irrigated with Hoagland nutrient solution every 3 days. It was time to pour in some different concentrations of iron solution $(0,2.5,5,10,20,30,40$ and $60 \mathrm{mg} / \mathrm{L})$ and blending with Hoagland nutrient solution after 7 days. There was each treatment repeating three times.

After one month with iron treatments, the mature leaves from the top of $P$. davidiana seedlings were collected for the assay of photosynthetic pigment of chlorophyll a, chlorophyll b, carotenoid and total chlorophyll, and the antioxidant enzyme activity of peroxidase (POD), catalase (CAT) and superoxide dismutase (SOD), the soluble protein content and the malondialdehyde (MDA) content as described by Hao et al [9]. By measuring the above date, studying the effects of iron solutions on physiological status of $P$. davidiana seedlings and knowing more the characteristics of iron in fruit trees.

\footnotetext{
*Corresponding author's e-mail: lman@sicau.edu.cn
} 


\subsection{Statistical analyses}

Statistical analyses were conducted to use statistical software of SPSS 17.0. Date was analyzed by one-way ANOVA with least significant difference at $5 \%$ confidence level.

\section{Results and discussion}

\subsection{The photosynthetic pigment content in $P$. davidiana seedlings}

Table 1. Photosynthetic pigment content in $P$. davidiana seedlings.

\begin{tabular}{cccccc}
\hline $\begin{array}{c}\text { Treatments } \\
(\mathrm{mg} / \mathrm{L})\end{array}$ & $\begin{array}{c}\text { Chlorophyll a } \\
(\mathrm{mg} / \mathrm{g})\end{array}$ & $\begin{array}{c}\text { Chlorophyll b } \\
(\mathrm{mg} / \mathrm{g})\end{array}$ & $\begin{array}{c}\text { Carotenoid } \\
(\mathrm{mg} / \mathrm{g})\end{array}$ & $\begin{array}{c}\text { Total chlorophyll } \\
(\mathrm{mg} / \mathrm{g})\end{array}$ & Chlorophyll a/b \\
\hline 0 & $1.224 \pm 0.031 \mathrm{e}$ & $0.240 \pm 0.005 \mathrm{~g}$ & $4.549 \pm 0.055 \mathrm{f}$ & $1.463 \pm 0.030 \mathrm{e}$ & $5.111 \pm 0.193 \mathrm{a}$ \\
2.5 & $2.204 \pm 0.107 \mathrm{~b}$ & $0.500 \pm 0.007 \mathrm{c}$ & $8.791 \pm 0.175 \mathrm{c}$ & $2.704 \pm 0.111 \mathrm{~b}$ & $4.412 \pm 0.187 \mathrm{~b}$ \\
5 & $2.219 \pm 0.092 \mathrm{ab}$ & $0.460 \pm 0.010 \mathrm{~d}$ & $9.181 \pm 0.239 \mathrm{~b}$ & $2.679 \pm 0.088 \mathrm{~b}$ & $4.827 \pm 0.263 \mathrm{a}$ \\
10 & $2.397 \pm 0.032 \mathrm{a}$ & $0.606 \pm 0.028 \mathrm{a}$ & $8.998 \pm 0.262 \mathrm{bc}$ & $3.003 \pm 0.053 \mathrm{a}$ & $3.963 \pm 0.154 \mathrm{c}$ \\
20 & $2.376 \pm 0.038 \mathrm{a}$ & $0.582 \pm 0.013 \mathrm{~b}$ & $9.815 \pm 0.185 \mathrm{a}$ & $2.957 \pm 0.032 \mathrm{a}$ & $4.087 \pm 0.136 \mathrm{c}$ \\
30 & $2.287 \pm 0.087 \mathrm{ab}$ & $0.600 \pm 0.018 \mathrm{ab}$ & $9.552 \pm 0.062 \mathrm{a}$ & $2.887 \pm 0.070 \mathrm{a}$ & $3.820 \pm 0.261 \mathrm{c}$ \\
40 & $2.027 \pm 0.029 \mathrm{c}$ & $0.420 \pm 0.007 \mathrm{e}$ & $8.446 \pm 0.160 \mathrm{~d}$ & $2.446 \pm 0.022 \mathrm{c}$ & $4.832 \pm 0.150 \mathrm{a}$ \\
60 & $1.915 \pm 0.026 \mathrm{~d}$ & $0.400 \pm 0.011 \mathrm{f}$ & $8.047 \pm 0.092 \mathrm{e}$ & $2.310 \pm 0.015 \mathrm{~d}$ & $4.851 \pm 0.200 \mathrm{a}$ \\
\hline
\end{tabular}

Values are means $( \pm \mathrm{SE})$ of 3 replicate pots. Different lowercase letters indicated significant differences among treatments at 0.05 levels.

From Table 1, the photosynthetic pigment content had an obvious dissimilarity $(p<0.05)$ between control and iron-treated $P$. davidiana seedlings and the chlorophyll a, chlorophyll b, carotenoid and the total chlorophyll content in treated $P$. davidiana seedlings were all significantly higher than that in control seedlings. When increased iron concentration up to $10 \mathrm{mg} / \mathrm{L}$, the chlorophyll a, chlorophyll $\mathrm{b}$ and the total chlorophyll content gradually rose, but decreased at iron concentrations of $20,30,40$ and $60 \mathrm{mg} / \mathrm{L}$. For the content of carotenoid, it was the highest at iron concentration of $20 \mathrm{mg} / \mathrm{L}$. The chlorophyll a/b ratio was all lower in treated seedlings compared to control seedlings. Also, the content of chlorophyll a, total chlorophyll and chlorophyll $\mathrm{a} / \mathrm{b}$ ratio had no significant difference $(p>0.05)$ at concentrations of iron solution 10 , 20 and $30 \mathrm{mg} / \mathrm{L}$.

\subsection{Antioxidant enzyme activity and osmotic adjuster content of $P$. davidiana seedlings}

Irrigating different concentrations of iron solution increased the activity of POD, CAT and SOD and it was the highest at iron concentration of $60 \mathrm{mg} / \mathrm{L}$ (Table 2). Compared with treated $P$. davidiana seedlings, the POD, CAT and SOD activity were all significantly lower $(p<$ 0.05 ) in control seedlings. At iron concentration of 30 $\mathrm{mg} / \mathrm{L}$, the soluble protein content in $P$. davidiana seedlings was the highest, but the lowest at $10 \mathrm{mg} / \mathrm{L}$. Irrigating the iron concentration of $60 \mathrm{mg} / \mathrm{L}$ was the best way to increase the MDA content, but it was the lowest when the application of iron concentration of $5 \mathrm{mg} / \mathrm{L}$. Compared to the seedlings with no iron solution, the growth and resistance to environment in treated $P$. davidiana seedlings would be better.

Table 2. Antioxidant enzyme activity and osmotic adjuster content of $P$. davidiana seedlings.

\begin{tabular}{cccccc}
\hline $\begin{array}{c}\text { Treatments } \\
(\mathrm{mg} / \mathrm{L})\end{array}$ & $\begin{array}{c}\text { POD activity } \\
(\mathrm{U} /(\mathrm{g} / \mathrm{min}))\end{array}$ & $\begin{array}{c}\text { CAT activity } \\
(\mathrm{mg} / \mathrm{g} / \mathrm{min})\end{array}$ & $\begin{array}{c}\text { SOD activity } \\
(\mathrm{U} / \mathrm{g})\end{array}$ & $\begin{array}{c}\text { Soluble protein } \\
\text { content } \\
(\mathrm{mg} / \mathrm{g})\end{array}$ & $\begin{array}{c}\text { MDA content } \\
(\mu \mathrm{mol} / \mathrm{kg})\end{array}$ \\
\hline 0 & $85.39 \pm 0.949 \mathrm{~g}$ & $2.725 \pm 0.107 \mathrm{~d}$ & $198.6 \pm 6.086 \mathrm{~d}$ & $28.33 \pm 0.235 \mathrm{e}$ & $31.81 \pm 0.230 \mathrm{e}$ \\
2.5 & $376.9 \pm 9.250 \mathrm{~d}$ & $6.046 \pm 0.089 \mathrm{a}$ & $212.0 \pm 9.938 \mathrm{a}$ & $34.01 \pm 0.846 \mathrm{~d}$ & $53.19 \pm 1.846 \mathrm{~b}$ \\
5 & $220.9 \pm 10.74 \mathrm{f}$ & $5.770 \pm 0.060 \mathrm{~b}$ & $182.6 \pm 5.586 \mathrm{~b}$ & $27.56 \pm 0.869 \mathrm{e}$ & $29.53 \pm 1.346 \mathrm{f}$ \\
10 & $209.9 \pm 7.387 \mathrm{f}$ & $5.431 \pm 0.125 \mathrm{c}$ & $159.5 \pm 3.754 \mathrm{c}$ & $25.38 \pm 0.877 \mathrm{f}$ & $30.28 \pm 1.282 \mathrm{f}$ \\
20 & $253.8 \pm 11.65 \mathrm{e}$ & $5.669 \pm 0.174 \mathrm{~b}$ & $169.1 \pm 4.506 \mathrm{~b}$ & $41.40 \pm 1.186 \mathrm{~b}$ & $35.54 \pm 1.031 \mathrm{~d}$ \\
30 & $409.3 \pm 18.48 \mathrm{c}$ & $5.824 \pm 0.199 \mathrm{ab}$ & $254.8 \pm 11.80 \mathrm{ab}$ & $47.56 \pm 1.018 \mathrm{a}$ & $29.68 \pm 1.400 \mathrm{f}$ \\
40 & $594.1 \pm 18.40 \mathrm{~b}$ & $6.037 \pm 0.131 \mathrm{a}$ & $254.7 \pm 10.07 \mathrm{a}$ & $36.22 \pm 1.353 \mathrm{c}$ & $46.86 \pm 0.415 \mathrm{c}$ \\
60 & $786.9 \pm 23.31 \mathrm{a}$ & $6.068 \pm 0.053 \mathrm{a}$ & $312.2 \pm 9.285 \mathrm{a}$ & $27.88 \pm 0.955 \mathrm{e}$ & $54.96 \pm 0.974 \mathrm{a}$ \\
\hline
\end{tabular}

Values are means $( \pm \mathrm{SE})$ of 3 replicate pots. Different lowercase letters indicated significant differences among treatments at 0.05 levels. 


\section{Conclusions}

This research was conducted to learn the effects of photosynthetic pigment, antioxidant enzyme activity and osmotic adjuster on $P$. davidiana seedlings by irrigating different concentrations of iron solution. Through data analysis, it showed that the chlorophyll a, chlorophyll $b$, carotenoid and the total chlorophyll content in treated $P$. davidiana seedlings were all significantly higher than that in control seedlings. The chlorophyll $\mathrm{a} / \mathrm{b}$ ratio in control seedlings was the lowest. Also, the activity of POD, CAT and SOD and the MDA content in irontreated $P$. davidiana seedlings were all higher than that in control seedlings. By and large, the photosynthetic pigment and antioxidant enzyme activity in iron-treated $P$. davidiana seedlings were higher than that in control seedlings, so irrigating iron solution was good for the growth and resistance of $P$. davidiana seedlings.

\section{Acknowledgments}

This work was financially supported by the Application Infrastructure Project of Science and Technology Department of Sichuan Province (2016JY0258).

\section{References}

1. Myers, S.S., Zanobetti, A., Kloog, I., Huybers, P., Leakey, A.D.B., Bloom, A.J., Carlisle, E., Dietterich, L.H., Fitzgerald, G., Hasegawa, T., Holbrook, N.M., Nelson, R.L., Ottman, M.J., Raboy, V., Sakai, H., Sartor, K.A., Schwartz, J., Seneweera, S., Tausz, M., Usui, Y. (2014) Increasing $\mathrm{CO}_{2}$ threatens human nutrition. Nature. 510: 139-142.

2. Santos, C.S., Deuchande, T., Vasconcelos, M.W. (2019) Molecular aspects of iron nutrition in plants. Prog. Bot., pp: 1-32.

3. Prasad, P.V.V. (2003) Plant nutrition: iron chlorosis. In: Thomas, B., Murphy, D.J., Murray, B.G. (Eds), Encyclopedia of applied plant sciences. Elsevier Academic Press, London.

4. Jeong, J., Connolly, E.L. (2009) Iron uptake mechanisms in plants: functions of the FRO family of ferric reductases. Plant Sci., 176: 709714.

5. Yue, L.J. (2009) Effects of iron stress on iron metabolism, photosynthesis and antioxidant system in pea seedlings. Lanzhou University, Gansu, China.

6. Wang, M. (2015) Application of nano-iron oxide in the prevention and control of iron deficiency yellowing disease in plants. Wuhan University of Technology, Wuhan, China.

7. Liu, J., Liu, Y.Q., Li, J., Sun, S.X., Wang, Y.Q. (2017) Effects of alkali stress on Prunus davidiana (Carr.) leaf morphological structure and photosynthetic characteristics. Southwest China J. Agric. Sci., 30: 327-332.
8. Zhang, C.L., Liu, F.X., Wang, Z.X., Liu, Z.Z., Jiang, L. (2019) Study on 'Xiacui' grafting on different seedling peach rootstocks. Northern Fruits, 25: 9-12.

9. Hao, Z.B., Cang, J., Xu, Z. (2004) Plant physiology experiment. Harbin Institute of Technology Press, Haibin, China. 